\title{
Maori pakeha differentials in incomes and hours worked: a study of sample data for selected occupations
}

\author{
Peter Brosnan*
}

Studies which compare Maori and non-Maori incomes have used either aggregate census data or a non-representative sample. This study uses 8 very restrictive samples drawn for the 4 occupations which employ the most Maori men and the 4 which employ the most Maori women. It is found that there are significant differences in the hours worked by the Maoris and pakehas in the samples. When hours worked plus age and location are controlled for there are no significant earnings differences for 7 of the 8 occupations. The results suggest that policies to improve Maori earnings must continue to be directed at the factors which affect occupational choice and job assignment.

\section{Introduction}

A substantial number of studies have compared Maori and non-Maori incomes and employment. These studies have identified a substantial gap between the earnings of Maoris and others but, due to inadequacies of their data, they have not been able to reach unambiguous conclusions concerning the nature of the Maori-non-Maori gap. This note reports the examination of a carefully drawn sample from the 1976 Census - the best data presently available - and this clarifies some issues raised in earlier studies.

\section{Previous studies}

The lower average incomes of the Maori population and Maori labour force have been well documented (Macrae, 1975; Brosnan, 1982; Brosnan and Hill, 1983A; Easton, 1983) and it has been found further that the income differentials between Maoris and Pakehas persist when we control for education and age (Brosnan, 1984). The origin of the MaoriPakeha earnings gap is not so easily explained. Previous works have suggested that the tifference is due to occupational discrimination (Macrae, 1975, 1976 and 1979; Brosnan, 1982; Brosnan and Hill, 1983A and 1983B). It is certainly true that Maoris are concentrated in occupations with less pay prestige and influence (Ritchie, 1968; Hill, 1979; Hill and Brosnan, 1984). Both Pierce (1975) and Macrae (1975) have discussed the role of race stereotyping by New Zealand employers and Spoonley (1978) has produced direct evidence that some employers do discriminate against Maoris and Pacific Island Polynesians $\mathrm{n}$ their hiring.

\footnotetext{
* Senior Lecturer, Industrial Relations Centre, Victoria University of Wellington. The author acknowledges the research assistance of Margaret Kelly and Lee Chak Tin and useful suggestions from Craig Hill, Pat Walsh and the referees. The research reported was made possible by Victoria University of Wellington Internal Research Grant No. 28/82. The data used in this paper were provided by the Department of Statistics using the CENTS-AID II facility.
} 
One of the most detailed studies of Maori-pakeha earnings was carried out a decade ago. John Macrae $(1975,1976$ and 1979) utilized a sample obtained for the records of a large company which employed a substantial number of Maoris. Macrae found evidence of occupational segregation according to race. He also found that Maoris tended to earn less than pakehas but he could find no "consistent evidence of racial discrimination" (Macrae, 1976, p. 16) in pay within the company after controlling for appropriate variables such as present and past experience, age, skill, overtime working and trade union strength. A significant conclusion was that "the most important determinants of wage inequality are variations in time spent working" (Macrae, 1975, p. 211) and further, that Maoris worked less overtime than pakehas. Why this was so, Macrae was not able to determine but his results did leave open the possibility of discrimination in the allocation of overtime.

Several criticisms could be directed at Macrae's work. His separation of the workforce into skilled and unskilled was not based on any objective criteria and his attribution of "trade union ranking" is also dubious. The applicability of the results is limited mainly by the fact that they apply directly to only one company, and one which may not be representative of other employers. The particular company is unusual in being large and, since it made its records available, it is likely that it saw itself as having an acceptable record in its treatment of workers of different races. We cannot be sure that other companies do not treat workers differently on the basis of race.

There is some evidence, however, that Macrae's findings might apply "on the average". It was suggested in a later paper by Brosnan (1982) that Maori and non-Maori women work different numbers of hours per week. Another paper which examined inter-industry differences in Maori-non-Maori income ratios concluded that "racial discrimination may be more pervasive and complex than just occupational segregation" (Brosnan and Hill, 1983A, p. 338). The data used in that study did not permit the further exploration of that hypothesis. However, for a later paper, Brosnan and Hill (1983B), were able to obtain unpublished data from the 1976 Census for individual occupations. The 20 occupations where most Maoris were employed were used in the analysis - there being too few Maoris in the remaining occupations to produce meaningful statistics. The findings from these data were again somewhat mixed. As far as males were concerned, Maoris had lower incomes for each occupation; the difference was greatest for shearers where Maori earnings were only 81 percent of non-Maori incomes and was the least for clerks where the Maori-non-Maori income ratio was 99 percent. Among females, Maoris out-earned non-Maoris in 15 of the 20 occupations. At one extreme, for shearers, Maori earnings were only 90 percent of the non-Maori earnings; at the other extreme, for the occupation, house and chambermaid, wardsmaid, home aid, Maori incomes were 18 percent higher than non-Maori incomes. The differential in favour of female Maoris occurred in a wide range of occupations including both manual, white collar and professional jobs, examples being factory labourer (differential 6 percent), clerk ( 6 percent) and primary school teacher ( 12 percent). These results were somewhat surprising given the results for males and Brosnan and Hill were drawn to the conclusion that they may be due to differences in the hours worked by Maori and non-Maori females (1983B, pp. 55-56).

Although the evidence did seem to stack up in favour of the hypothesis that there were important differences in the hours worked by Maoris and Pakehas, these papers, and others, had suggested further reasons for both the male and female Maori-pakeha earnings gap: the rural location of relatively more Maoris, higher Maori unemployment rates, the higher proportion of the Maori labour force who are wage or salary earners, the lesser Maori educational level and the more youthful Maori population (Department of Statistics, 1981, p. 16).

\section{Method}

In order to control for the factors listed in the previous paragraph and the short- 
comings of earlier research reviewed above, we decided to analyse a restricted sample of census data for specifically defined occupations. The analysis had 2 aims. First to test whether hours worked in the census week were independent of race; and secondly, after controlling for hours worked, to determine whether income classification was independent of race. The samples were drawn, for each sex, for the 4 occupations which Brosnan and Hill (1983B) found accounted for the most Maori employment. The small numbers in the sample and the requirements of the analysis did not permit the profitable extension to occupations employing fewer Maoris.

\section{Data}

Samples were drawn from the census using the 10 percent CENTS-AID II facility. The sampling was limited to persons: (a) born in New Zealand, (b) aged less than 60 years, (c) wage and salary earners, (d) not having received unemployment, sickness or invalids' benefit in the period for which they reported earnings, and (e) with secondary school education only. Ideally we would have selected persons with a specific number of years of secondary schooling but this census had not collected these data. Each sample was drawn separately for 2 ethnic groups, New Zealand Maori ( $1 / 2$ or more Maori origin) and Europeans (pakeha) and was stratified by age, hours worked in the census week, urban or rural location, annual income and occupation.

Two factors necessitated that the number of levels for each variable be constrained. First, the CENTS-AID II facility has a maximum number of cells which it will produce. Secondly, given the small number of Maoris in each occupation, a large number of levels for the variables would produce many zero-entry cells. Consequently all variables were grouped into broader categories. Five age groups were utilized: 15-19, 20-24, 25-34, $35-49$ and 50-59. Hours worked were also identified in 5 categories $20-34$ hours, $35-40$ hours, 41-45 hours, 46-50 hours and above 50 hours. The criterion for classification as urban location was that the person resided in one of the 24 main urban areas (MUAs). All other locations were designated rural. The income classifications were condensed to 3 levels; low (\$1 - \$2 999), medium (\$3 $000-\$ 5999)$ and high $(\$ 6000-\$ 19999)$. The highest census category, $\$ 20000$ plus, was not reported by any of our sample.

The sample sizes, the mean incomes and their ratios are reported in Table 1. It is convenient for our analysis that the 8 occupations are ones where few employees are salaried (at least in the sense of weekly pay being unaffected by hours worked in the week). Thus, although our sample is for wage and salary earners, nearly all our sample will be wage earners. A further advantage is that relatively few of the individuals in these occupations would have substantial investment incomes. Thus the incomes reported would be largely wages.

The use of a sample rather than the corresponding population introduces the possibility of sampling error. For this reason, and because our sample is drawn from a different population than was the data presented in Brosnan and Hill (1983B), and since our data are means rather than medians, ${ }^{1}$ we should expect the ratios in Table 1 to differ from Brosnan and Hill's (1983B). However, they correspond very closely for 6 occupations and for the other 2 (freezing workers, general) $(0.80 \mathrm{cf} 0.87)$ and housemaids etc. (1.07 cf 1.18) they are consistent with the confidence intervals for the sample.

Using a sample has, however, the important advantage that the statistical tests are appropriate. As is well known, when data for the whole census is used, all effects tend to appear significant because of the very large numbers involved, (e.g. Bishop et al., 1975,

1. Brosnan and Hill (1983B) used medians because the open class at the top of the income, range, $\$ 20000$ plus, necessitates certain assumptions if the mean is to be calculated. The mean was used here because none of the sample reported incomes as high as $\$ 20000$ plus and, with the smaller numbers in each income group, the median would be less reliable. 


\section{Peter Brosnan}

Table 1: Maori and pakeha incomes

\begin{tabular}{|c|c|c|c|c|c|c|}
\hline \multirow[b]{2}{*}{$\begin{array}{l}\text { NZSCO } \\
\text { code }\end{array}$} & \multirow[b]{2}{*}{ Occupation } & \multicolumn{2}{|c|}{ Maori } & \multicolumn{2}{|c|}{ Pakeha } & \multirow[b]{2}{*}{$\begin{array}{l}\text { Maori-pakeha } \\
\text { ratio }\end{array}$} \\
\hline & & $\begin{array}{l}\text { Sample } \\
\text { size } \\
n\end{array}$ & $\begin{array}{c}\text { Mean } \\
\text { Income } \\
\$\end{array}$ & $\begin{array}{l}\text { Sample } \\
\text { size } \\
n\end{array}$ & $\begin{array}{c}\text { Mean } \\
\text { Income } \\
\$\end{array}$ & \\
\hline \multicolumn{7}{|l|}{ Male } \\
\hline 7736 & $\begin{array}{l}\text { Freezing worker } \\
\text { (general) }\end{array}$ & 294 & 4382 & 649 & 5478 & 0.80 \\
\hline 9541 & $\begin{array}{l}\text { Carpenter and/or } \\
\text { joiner }\end{array}$ & 62 & 5266 & 699 & 5332 & 0.99 \\
\hline 7732 & $\begin{array}{l}\text { Other freezing and } \\
\text { abattoir worker }\end{array}$ & 65 & 4804 & 147 & 5684 & 0.85 \\
\hline 9711 & Waterside worker & 75 & 6317 & 227 & 6992 & 0.90 \\
\hline \multicolumn{7}{|l|}{ Female } \\
\hline 7951 & Sewing machinist & 143 & 2668 & 693 & 2658 & 1.00 \\
\hline 3931 & Clerk & 102 & 3767 & 2102 & 3564 & 1.06 \\
\hline 3511 & Shop assistant & 63 & 2361 & 1714 & 2580 & 0.92 \\
\hline 5401 & $\begin{array}{l}\text { House and chambermaid } \\
\text { wardsmaid, home aid }\end{array}$ & 77 & 2477 & 229 & 2305 & 1.07 \\
\hline
\end{tabular}

Source: 1976 Census of population and dwellings

Knoke and Burke, 1980). By using a sample only we avoid this problem.

The occupations for which the samples were derived accounted for approximately 13 percent of male Maori wage and salary earners and 18 percent of female wage and salary earners.

\section{Analysis}

The data were analysed by computer and various log-linear models were fitted to the data. ${ }^{2}$ Two analyses were carried out. First, models were fitted with hours worked as a respohse variable. The aim here was to test whether, as Macrae (1975) suggested, Maori men worked significantly less hours than pakeha men and/or whether, as Brosnan (1982) suggested, Maori women worked significantly more hours than Pakeha women. Secondly, models were fitted with income as a response variable. The aim this time was to test whether there was a significant relation between income and ethnic origin when hours, location, age and occupation were controlled for. In fitting the models, a forward selection procedure was used; terms were added to the model in the sequence in which they improved the fit per degree of freedom lost. The variables (factors) are presented in Tables 2 and 4, below, in the order in which they were chosen by the fitting algorithm.

2. Log-linear models are used in the analysis of multi-dimensional contingency tables. Among other things, they allow the researcher to determine whether classification in one dimension is independent of classification in another dimension and to determine odds factors. For example, whether income is independent of ethnic origin and how the odds of an individual having a certain income are affected by their being Maori or being pakeha. Full descriptions of these techniques can be found in Bishop et al. (1975), Haberman (1978), Knoke and Burke (1980) and Upton (1978). 


\section{Results}

\section{Hours worked}

The results of analysing the 5 demensional tables of hours worked by location, occupation, age and ethnic origin are presented in Table 2 . Immediately apparent will be the ommission of the variable location from the table. This factor was not included in the model since the algorithm determined that it did not significantly improve the fit of the model. Since the other factors are presented in the order in which they improve the fit of the model, we see that for males, occupation is the most important determinant of hours worked while age is the least. For females, occupation is more important than ethnic origin but age is the most important factor. This strong association between age and the hours worked by females parallels the well known phenomena that female labour force participation rates ${ }^{3}$ vary substantially with age. This, it would appear that age affects both the decision to work or not work and, for women who do work, the quantity of work time offered.

Table 2: Determinants of hours worked

\begin{tabular}{lccc}
\hline Factor & $\begin{array}{c}\text { Log likelihood } \\
\text { ratio }\left(\chi^{2}\right)\end{array}$ & $\begin{array}{c}\text { Degrees of } \\
\text { freedom }\end{array}$ & $\begin{array}{c}\text { Significance } \\
\text { level }(\%)\end{array}$ \\
\hline Males & & & \\
Occupation & 476.61 & 12 & 0.000 \\
Ethnic origin & 90.76 & 4 & 0.000 \\
Age & 32.79 & 16 & 0.795 \\
Females & & 16 & \\
Age & 388.23 & 12 & 0.000 \\
Occupation & 154.58 & 4 & 0.000 \\
Ethnic origin & 43.47 & & 0.000 \\
\hline
\end{tabular}

Our interest is primarily in the effect of ethnic origin on hours worked. We note that there is a highly significant relation between the 2 variables for both sexes. Of particular interest is the exact nature of the relationship. This is revealed by the relevant parameters of the model which are presented in Table 3. The parameters are simple to interpret. They are numerical factors by which the odds of being in a particular hours worked category change according to ethnic origin. The odds for each individual are the product of the odds for all the relevant parameters. However, we are interested in the contribution of ethnicity to the total odds. Thus we note, for example, from the first row that for males, being Maori reduces the odds of working 20-34 hours a week (as opposed to all other ranges of hours) by 8.6 percent while being Pakeha increases them by 9.4 percent.

Table 3 shows that the effect of ethnic origin on hours worked is somewhat different for each sex. Being Maori increases the odds of a male working 35-40 hours but reduces the odds of working 20-34 hours and, as Macrae (1975) found too, it reduces the odds of

3. Participation rates (R) are the proportion of an age group who are in the labour force:

$$
\mathrm{R}=\frac{\text { work force aged } x}{\text { population aged } x} \times 100
$$


88 Peter Brosnan

Table 3: Parameters: Hours worked with ethnic origin

\begin{tabular}{lccccc}
\hline & \multicolumn{3}{c}{ Male } & & \multicolumn{2}{c}{ Female } \\
\cline { 2 - 3 } \cline { 5 - 6 } Hours worked & Maori & Pakeha & & Maori & Pakeha \\
\hline $20-34$ & 0.914 & 1.094 & & 0.775 & 1.291 \\
$35-40$ & 1.529 & 0.654 & & 1.256 & 0.796 \\
$41-45$ & 0.941 & 1.063 & & 0.758 & 1.319 \\
$46-50$ & 0.845 & 1.183 & & 1.232 & 0.812 \\
51 plus & 0.901 & 1.110 & & 1.100 & 0.909 \\
\hline
\end{tabular}

working more than the standard 40 hours. Conversely, being pakeha increases the odds of males working 20-34 hours or above 40 hours. For females, on the other hand, being Maori increases the odds of working $35-40$ hours but it also increases them for the 46-50 hours and for 51 hours plus. Conversely, being pakeha increases the odds for females of working 20-34 hours or 41-45 hours. The higher odds factors for Maori women for the 45-50 and 50 hours plus categories support Brosnan's (1982) hypothesis that Maori women's higher earnings are due to longer hours worked.

Further investigation into the relation between hours worked and ethnicity revealed no identifiable pattern by occupations.

\section{Income}

Given the significant differences in hours worked, according to age, occupation and ethnic origin, we should expect that these factors would also affect a person's income level. Log linear analysis of the 6-way table of income by hours worked by location, occupation, age and ethnic origin confirmed that this was so. However, we may wish to know whether these factors affect income when we control for hours worked. The results of such analysis are represented in Table 4.

Table 4: Determinants of income level

\begin{tabular}{lccc}
\hline Factor & $\begin{array}{c}\text { Log likelihood } \\
\text { ratio } x^{2}\end{array}$ & $\begin{array}{c}\text { Degrees of } \\
\text { freedom }\end{array}$ & $\begin{array}{c}\text { Significance } \\
\text { level (\%) }\end{array}$ \\
\hline Males & & & \\
Hours worked & 251.65 & 8 & 0.000 \\
Age & 586.67 & 8 & 0.000 \\
Location & 23.76 & 2 & 0.001 \\
Ethnic origin & 13.49 & 6 & 0.118 \\
Occupation & 46.60 & & 0.000 \\
Females & & 8 & 0.000 \\
Hours worked & 675.62 & 6 & 0.000 \\
Age & 983.07 & 2 & 0.000 \\
Occupation & 423.31 & & 0.000 \\
Location & 24.85 & & \\
\hline
\end{tabular}


The variable hours worked was added to the model first. The other factors were then added in the order in which they improved the fit. We see from Table 4 that, even when we control for hours worked, all factors are significant determinants of male income and all except ethnic origin are significant determinants of female income. The relative importance of the factors varies between the sexes; except for age which is the most important factor for both sexes (for females it actually exceeds hours worked in explanatory power). This is not surprising, since age is a proxy for experience. In the case of carpenters/joiners, age will distinguish apprentices from journeymen. Some of the other occupations included here, although not apprenticed trades, do have youth rates in their awards.

Although there is a significant association between ethnic origin and income for males, the factor was only fitted fourth of the 5 variables. The actual parameters for the interaction of male income and ethnic origin are given in Table 5. As we noted above there was no significant interaction of income and ethnic origin for females so the female parameters are not presented (they are zero in the model fitted). Looking at Table 5, we see that, allowing for the effects of hours worked, age, occupation and location, being Maori increases the odds of low or medium income (reduces the odds of high income). Conversely, being pakeha increases the odds of having high income (reduces the odds of low or medium income) by 29 percent.

Table 5: Parameters : Income with ethnic origin : Males

Income (\$)

Male

\begin{tabular}{lll} 
& Maori & Pakeha \\
\hline Low (\$1-2 999) & 1.245 & 0.803 \\
Medium (\$3 000-5 999) & 1.035 & 0.966 \\
High (\$6 000 plus) & 0.775 & 1.291 \\
\hline
\end{tabular}

A detailed examination of the fit of the models in Table 4 found that most outliers for the male data occurred for the occupation freezing worker (general). Outliers among the females data occurred more commonly for the occupations of clerk and sewing machinist. There was no clear pattern of outliers associated with the age, hours or location classifications except that male outliers occurred more often for the 25-34 age group and female outliers for the 15-19 age group.

In view of the pattern of outliers, separate log-linear models were fitted for each occupation and age group. This exercise revealed that the association of ethnic origin and income for males (which has been the least statistically significant association) was significant only for freezing workers (general) aged 25-49. Further, most of the variation associated with ethnic origin for that occupation occurred for the 25-34 age group. A smaller, but significant (at the 5 percent level), amount of the variation was associated with the 35-49 age group.

Were it not for the significant association between income and ethnic origin for freezing workers aged 25-49, we could conclude reasonably that Maoris and pakehas received the same pay for the same work in the same location. Are there features of the data or the occupations which allow us to still draw this conclusion?

The income variable relates to annual income while occupation is as at the date of the census. When we bear in mind that the freezing industry is seasonal, this is possibly responsible for the different incomes reported by Maoris and pakehas. If Maoris were less likely to have year round employment in the works and worked at other lesser-paid occupations in the off-season, they would have lower incomes. Two pieces of evidence tend to support this explanation. First the significant association of income and ethnic 
origin only occurs for 2 age-groups only and it is stronger for the 25-34 age group which is the age group from which migrant freezing workers typically come. Secondly, there is no significant effect of ethnic origin for the other related occupation studied here, namely occupation 7732 , other freezing and abattoir workers, a group who tend to have year round employment.

\section{Discussion and conclusion}

The research reported here has attempted to overcome a shortcoming of previous studies. These studies had either used a non-representative sample or used the total census population or total census labour force which, by its nature, is very heterogeneous. Thus the possibility always existed that the differentials reported were due to the sampling or the heterogeneity. This study, instead, has been based on a very carefully chosen sample; one which excluded employers, self employed, or unemployed persons, most salary earners, those who had attended any tertiary educational institution (irrespective of whether they obtained any qualification) and those whose earnings may have been reduced by being off work due to invalidity, sickness or unemployment during the preceding 12 months. The sample was restricted to New Zealand born persons of either Maori or European origin. It was limited further, for each sex, to the 4 occupations which employed the most Maoris.

The results reported in the preceding section indicate 2 important phenomena. First, there are significant differences in the patterns of hours worked by Maoris and pakehas. Secondly, when we control for these hours worked, plus age and location, (and birthplace, education, employment status and extended time off work), Maori and pakeha incomes are not significantly different for 7 of the 8 occupations studied and the significant differences in freezing worker's annual incomes may be due to the seasonal nature of the industry.

While it is in one sense reassuring to confirm, with entirely different data, Macrae's (1976) finding of no significant difference in the pay rates received by different ethnic groups, we should not lose sight of the fact that, in the aggregate, Maori incomes are only 81 percent of non-Maori incomes for males and 88 percent for females (Brosnan and Hill, 1983B). The findings of this paper, taken together with the previous research (outlined above), show that the differences, which appear large and significant at the aggregate level, are in fact due to differences in age, occupation and hours worked. Differences due to differential rates of pay according to race are either non-existent or too small to be identified unambiguously. It follows then that we ought to direct our attention to decisions determining occupational choice or job assignment (such as the nature of previous employment experience or qualifications obtained) and to the causes of differences in hours worked - especially overtime.

Clearly more work is needed to uncover the forces responsible for occupational concentration and the differential in hours worked between Maoris and pakehas. The lesser education of Maoris, employer stereotyping and prejudice (Ritchie, 1968; Macrae, 1975; Spoonley, 1978) and segregated information flows (Macrae, 1979) obviously go some way toward explaining the occupational concentration. Explaining the significant differences in hours worked is more problematic. Given that pakehas have a higher probability of being employers and that many short hour jobs are given to friends and relatives, it is not surprising to find from Table 3 that Maoris are less likely to work 20-34 hours per week but the forces which increase the odds of female Maoris working long hours needs further investigation. Although this analysis has supported the previously articulated hypotheses that Maori men are less likely to work overtime (Macrae, 1975) and that Maori women are more likely to do so (Brosnan, 1982), it has not explained this asymetry. Our data set did not differentiate among married and non-married women, nor among those with children; a clue to the different hours worked may be found in an analysis of Maori and 
pakeha female participation rates ${ }^{4}$ according to marital status and other household income. Such an analysis is presently being undertaken by the author and a colleague. It is hoped to be able to offer the results to this journal in due course.

As far as policy is concerned, the results reported here tend to suggest that the policies in place which aim to reduce prejudice and discrimination in hiring are pointed at the right variables. Similarly those schemes which endeavour to help Maoris become better qualified and thus move into areas where they are under-represented are also well directed. Nonetheless, much effort must be expended on many fronts if the incomes of Maoris are to be raised in the aggregate to equality with the incomes of pakehas'.

\section{References}

Bishop Y M M, Feinberg S E and Holland P W (1975) Discrete multivariate analysis Cambridge, Mass, MIT Press.

Brosnan P (1982) Ethnic origin and income in New Zealand New Zealand population review 8(3): 58-68.

Brosnan P (1984) Age, education and Maori-Pakeha income differences New Zealand economic papers 18: 49-61.

Brosnan P and Hill C (1983A) New Zealand Maori/non-Maori labour force income differentials Journal of industrial relations 25(3): 327-338.

Brosnan P and Hill C (1983B) Income, occupation and ethnic origin in New Zealand New Zealand economic papers 17: 51-57.

Department of Statistics (1981) New Zealand Census of Population and Dwellings 1976: Maori population and dwelling (Volume 8), Wellington.

Easton B (1983) Income distribution in New Zealand Wellington, NZIER.

Haberman S J (1978) Analysis of qualitative data Chicago, Academic Press (2 Vols).

Hill C and Brosnan P (1984) The occupational distribution of the major ethnic groups in New Zealand New Zealand population review 10(1): 33-42.

Hill M H (1979) Maori and non-Maori occupational differentiation: New Zealand 19511976. Presented to New Zealand Sociological Association Conference, Wellington, August.

Knoke D and Burke P J (1980) Log-linear models Beverly Hills, Sage.

Macrae J T (1975) The Maori in the New Zealand economy. Thesis (PhD), University of London, London.

Macrae J T (1976) Past and present experience and the distribution of wage earnings by race and skill Auckland, Department of Economics, University of Auckland (mimeo).

Macrae J T (1979) Maoris Islanders and Europeans. In S Wallman (Ed.) Ethnicity at work London, Macmillan.

Pierce B F (1975) Maori work behaviour. In I H Kawharu (Ed.) Conflict and compromise Wellington, Reed.

Ritchie J E (1968) Workers. In E Schwimmer (Ed.) The Maori people in the NineteenSixties Auckland, Longman.

Spoonley P (1978) The multi-cultural work force : The role of employers as gatekeepers New Zealand journal of industrial relations 3: 63-70.

Upton G J (1978) The analysis of cross-tabulated data Chichester, Wiley.

1. The term participation rate is defined as in footnote 3 . 